\title{
Location of Zinc in Trichomes of the Plant Picris divaricata
}

Gary R. Bauchan ${ }^{1}$, C. Leigh Broadhurst ${ }^{2}$, Charles Murphy ${ }^{1}$, Chris Pooley ${ }^{1}$, and Rufus L. Chaney ${ }^{2}$

${ }^{1}$ USDA- ARS, Electron \& Confocal Microscopy Unit, Building 012, BARC-West, Beltsville, MD 20705 USA gary.bauchan@ars.usda.gov

${ }^{2}$ USDA-ARS, Environmental Management and Byproducts Utilization Lab., Building 007, BARC-West, Beltsville, MD 20705

Large areas of cultivated land in China, Japan and Thailand have been contaminated with lead $(\mathrm{Pb})$, zinc $(\mathrm{Zn})$ and cadmium $(\mathrm{Cd})$ to the extent that demonstrable effects on human health have been reported. The extent of contamination virtually prohibits either removal of soils or agricultural utilization. Phytoremediation, the use of plants to extract toxic metals from soils, is one of the only viable options to relatively quickly remove excess metals from soils and return them to safe, productive use. Consequently there is a need for plants native to tropical and subtropical Asia that are suitable candidates for phytoremediation.

Picris divaricata Vant., a plant native to subtropical China, was recently identified as the first $\mathrm{Zn} / \mathrm{Cd}$ hyperaccumulator from the Asteraceae family [1,2]. Wild seed of $P$. divaricata was grown in a series of $\mathrm{pH}$ buffered test soils with $\mathrm{Zn}$ levels $00-7000 \mathrm{gkg}^{-1}$ and Cd levels $00-150 \mathrm{gkg}^{-1}$ for four months. Low Temperature-Scanning Electron Microscopy (LT-SEM) (Hitachi 4700 FE-SEM with a Quorum PP2000 Cryo-Prep chamber attached) was utilized to study the surface of the leaves to discern types of trichomes present. $P$. divaricata has multicellular simple trichomes concentrated on the leaf edge and midrib (Figure 1). A Variable Pressure SEM (Hitachi 3700 VP-SEM) and a Deben Cool Stage Peltier stage with an Oxford Instruments INCA ${ }^{\circledR}$ Electron Diffraction System (EDS) were utilized for elemental analysis. The EDS analysis showed that $\mathrm{Zn}$ is localized in the larger trichomes and epidermal cells adjacent to the trichome but virtually absent in other leaf tissues (Figure 2). Within the trichomes, $\mathrm{Zn}$ is localized in ovate spots (bright white) around the tips of individual cells. Spot EDS analysis showed that $\mathrm{Zn}$ concentrations ranged from 3 to $20 \mathrm{wt} \%$ when the beam was focused on the ovate spots and $4-7 \% \mathrm{Zn}$ at the base of trichomes (Figure 3).

These tips and other locations in the trichome cell contained black electron dense material when examined with transmission electron microscopy as determined with a JOEL JEM2100F (Figure 4). Silicon ( $\mathrm{Si})(1.4 \%)$ and Manganese $(\mathrm{Mn})(0.95 \%)$ were concentrated in the same areas as $\mathrm{Zn}$ (Figure 3). $\mathrm{Si}$ has been previously associated with alleviating $\mathrm{Zn}, \mathrm{Mn}$ and $\mathrm{Cd}$ toxicity; our results support this however, further investigation is warranted. Calcium $(\mathrm{Ca})(11 \%)$ and Potassium $(\mathrm{P})(7 \%)$ were concentrated in the distal tips of trichomes (Figure 3), similar to patterns previously observed for calcicole plants grown in elevated $\mathrm{Ca}$ soils. In conclusion, we have shown that these plants do accumulate heavy metals $\mathrm{Zn}$ and $\mathrm{Cd}$, thus, they have the potential for use in soil phytoremediation [3].

\section{References}

[1] Tang, Y-T., et al. Int. J. Environ Poll. 38 (2009) 26-38.

[2] Ying, R-R., et al. J. Plant Phys. 167 (2010) 81-87.

[3] Broadhurst, C.L. et al. Environ Exp. Bot. 87 (2013) 1-9. 


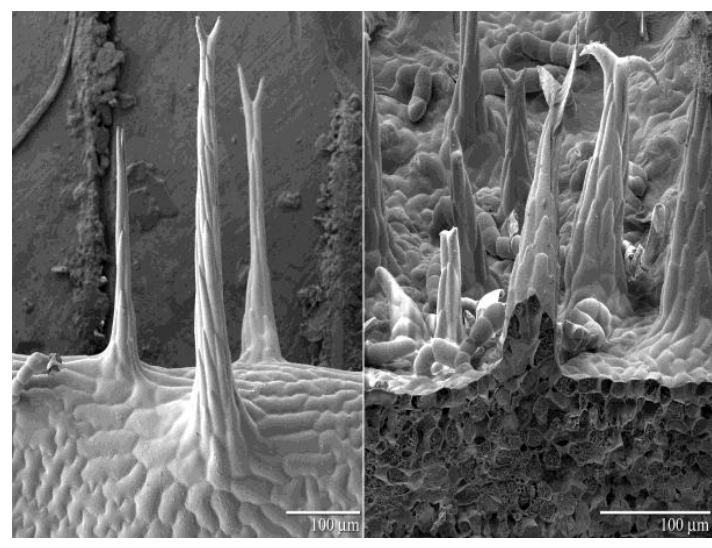

Figure 1. LT-SEM of leaf trichomes

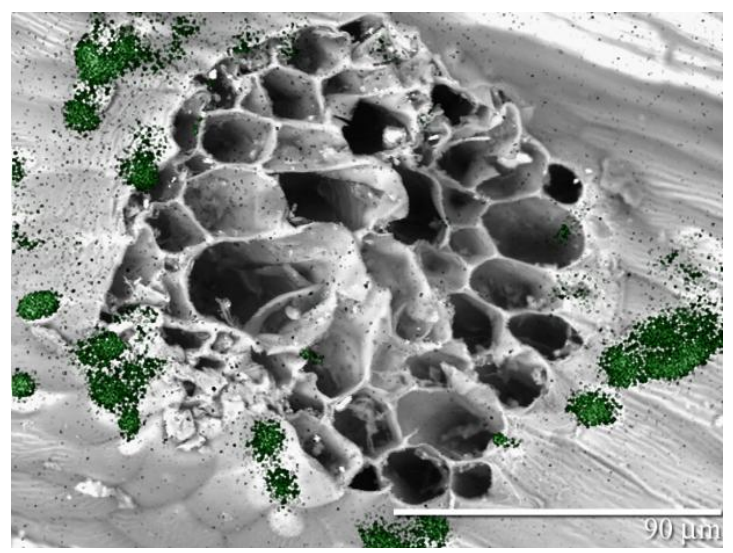

Figure 2. Base of freeze fractured trichome. Green $=\mathrm{Zn}$

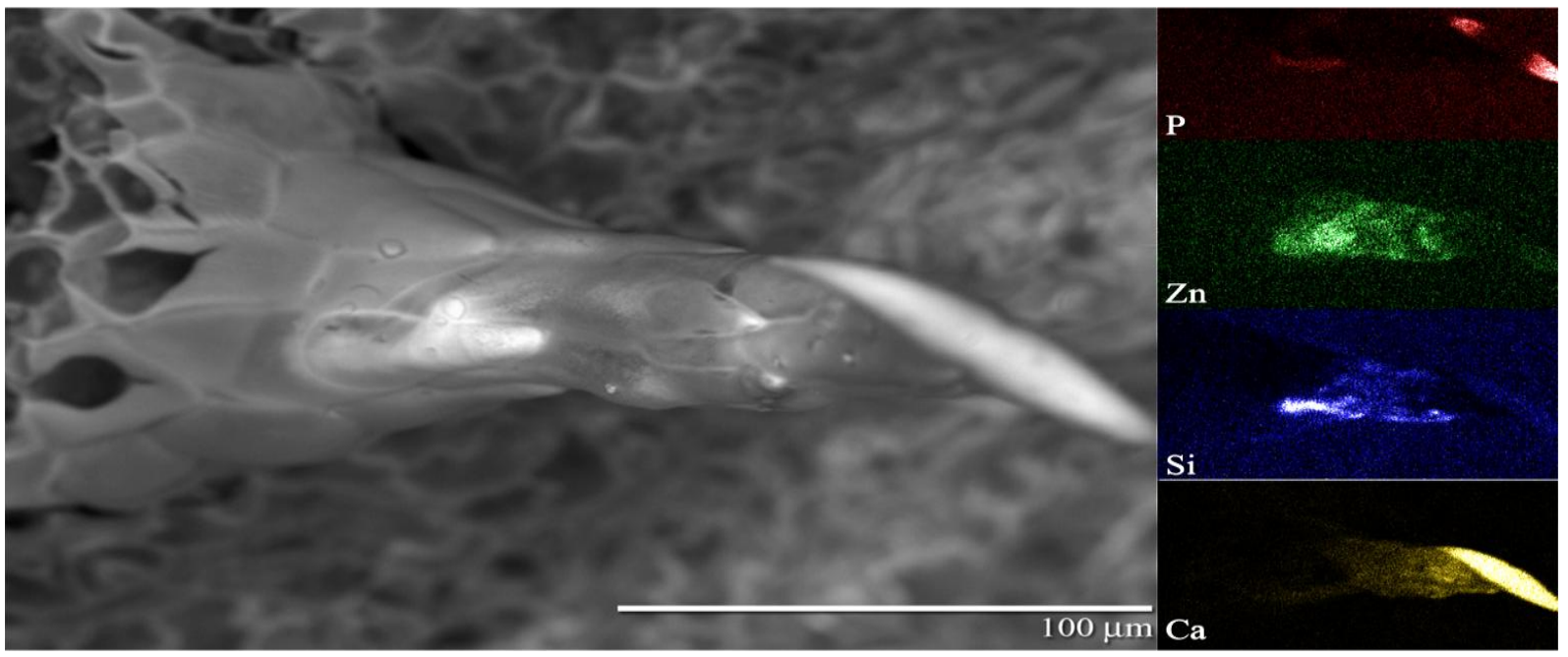

Figure 3. Whole trichome VP-SEM with EDS analysis. Location of P (red), Zn (green), Si (blue), $\mathrm{Ca}$ (yellow). White areas in colored images are highest metal concentrations.
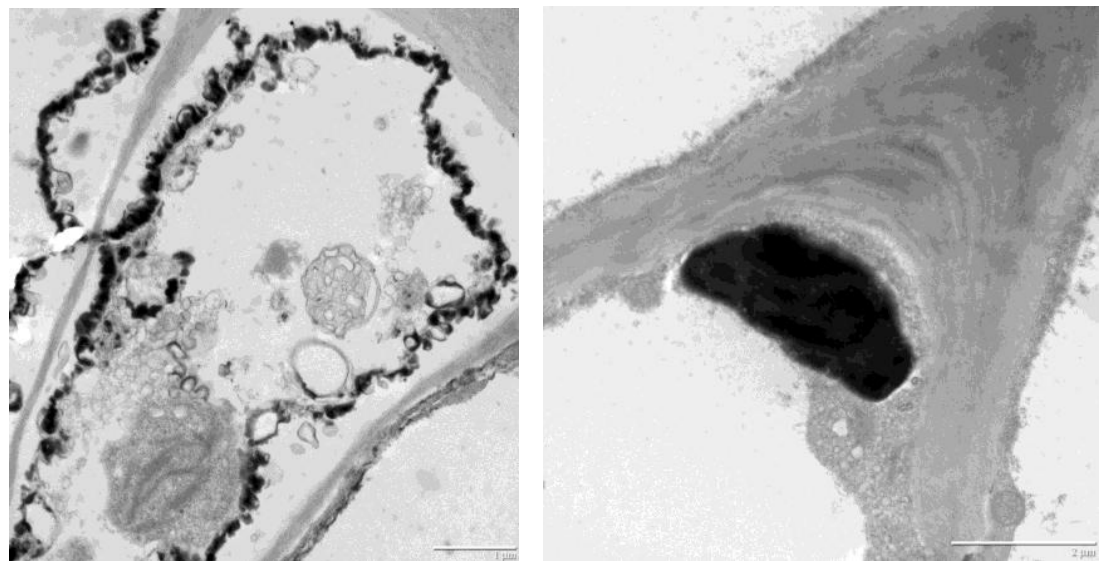

Figure 4: TEM of trichome cell with electron dense deposits 